\title{
Other Corporate Information Sources Usage: Evidence from Jordanian Individual Investors
}

\author{
Fawzi Al Sawalqa \\ Accounting Department, Financial \& Administrative Sciences Faculty, Tafila Technical University \\ P.O. Box 179, Tafila 66110, Jordan \\ Tel: 962-77-679-1650 E-mail: fawzi2000sawalqa@yahoo.com
}

Received: February 6, 2012

Accepted: February 23, $2012 \quad$ Published: April 1, 2012

doi:10.5539/ibr.v5n4p81

URL: http://dx.doi.org/10.5539/ibr.v5n4p81

\begin{abstract}
This study aims to provide insight into of the extent of usage of other corporate financial information sources by Jordanian individual investors in taking their investment decisions in Amman Stock Exchange (ASE) in comparison with annual corporate reports. The study also aims to identify the main reasons for using sources of information other than corporate annual reports. The result of study revealed that corporate annual report was the most used sources of information. This followed by published daily share price, newspapers and magazines, corporate web sites, advice of friend, tips and rumours, stockbrokers' advice and discussion with company staff respectively. These results indicated that Jordanian individual investors put more emphasis on the usage of the written sources than verbal sources. The results also indicated that Jordanian individual investors start to give more attention to the usage of electronic sources as the corporate web sites ranked forth. In respect to reasons that encouraged investors to use sources of information other than corporate annual reports, the results indicated that the first three reasons include; easier to get information, containing new information and giving up-to-date information. These reasons form the features of the written sources which were indicated as the most used sources of information.
\end{abstract}

Keywords: Corporate annual reports, Corporate information sources, Individual investors, Amman stock exchange, Jordan

\section{Introduction}

Accounting information is useful and effective when it supports decision-making. Optimal decision support is the main purpose of accounting information that corresponds to decision usefulness (Bagaeva, 2008). However, a big change has been taken place in the current Jordanian business environment which was created many other sources for financial information. This research seeks to contribute to the development of knowledge in this field in Jordan as a developing country and to identify the main other information sources that used by individual investor for invest decision-making.

Different regulative institutions and laws have played an important role in developing accounting in Jordan. These include for example, Amman Stock Exchange (ASE), Jordanian Association of Certified Public Accountants (JACPA), Income Tax Law, General Sales Tax Law and Companies Law. In addition, Jordan has been under pressure to use and enforce international accounting standards, exerted by several international institutions including the International Accounting Standards Board (IASB), the International Federation of Accountants (IFAC), the International Organization of Securities Commissions (IOSCO), the World Bank, and the International Monetary Fund (IMF).

The above discussion revealed that different regulative institutions have played an important role in developing and increasing the information content of Jordanian corporate annual reports. However, Abu-Nassar and Rutherford (1996) findings suggested that there is a need for further research on the use of information other than corporate annual reports specifically in the context of less-developed countries (see also Abu-Nassar \& Rutherford, 1995). Consequently, the current study seeks to answer the following two questions from the perspective of individual investors:

Question One: What is the extent of usage of other financial information sources by individual investors in taking their investment decisions in ASE in comparison with corporate annual reports?

Question Two: What are the main reasons for using sources of information other than corporate annual reports? 
The reminder of the paper is organised as follows. Section two presents the relevant literature in the subject. Section three describes the data collection process. Section four reports the finding of the study. Section five concludes the study.

\section{Previous Literature}

The frequency and timing of financial reporting vary from one country to another (Alford, Jones, Leftwich \& Zmijewski, 1993). In terms of the extent of usage of various sources of corporate information, Baker and Haslem (1973) found that individual investors in USA depended mainly on stockbroker's advice as the main source of information to take their investment decision. Scott and Smith (1992) findings indicated that newspapers, trade journals, other financial reports, advisory services and direct contact with company officials are the most used sources of information in taking investment decisions. In UK, Bartlett and Chandler (1997) asked respondents to indicate which other sources of information they read thoroughly or briefly. The findings of the study indicated that financial press reports were the most widely read. This followed by full corporate annual reports, interim financial statements, summary annual financial statements, preliminary announcements, stockbrokers' reports, Teletext or other TV media and DataStream or other computer software respectively. In Saudi Arabia, Al-Abdulqader, Hannah and Power (2007) listed ten sources of information available to Saudi investors and showed that respondents frequently use company quarterly reports as their main source of information. Newspapers and company annual reports come second and third respectively. These followed by financial statements, banks, Saud Arabia Monetary Agency (SAMA), statistical and information services, advice from friends, tips and rumours and discussion with company staff respectively. In USA, Loibl and Hira (2009) asked respondents to rank the frequency of their use of information sources including five internet-based sources (general internet search; internet trading; market watch websites; investment analysis or management software; and email investment newsletters); three mass media sources (newspapers, magazines, newsletters, or books; TV programs; and radio programs); four interpersonal sources (friends or colleagues; classes or workshops; investment clubs; and financial advisors); and one workplace-based source. Based on study findings, it is reasonable to assume that an information search on financial markets can only to some limited extent become automatic. In this regard, Abdelsalam and Street (2007) argued that companies in England and Europe should voluntarily focus on improving the timeliness of corporate internet reporting.

Investors believed that corporate annual reports are generally correct and complete but criticized them as being too promotional and biased to be completely objective. In addition, despite the fact that almost half of American investors hold the bachelor's degree or higher, annual reports are considered by many users to be difficult to understand (Scott \& Smith, 1992). Abu-Nassar and Rutherford (1996) also found that Jordanian users faced difficulties in understanding the various accounting polices reported at annual reports (Courtis, 2004). Furthermore, Jordanian users indicated that the most important reasons given for using alternative sources of information were that the information they provided was more up to date and that the other sources gave information not found in annual reports. Mirshekary and Saudagaran (2005) indicated that annual reports were deficient in providing the necessary information due to a lack of adequate detail and a delay in publishing. However, Mirshekary and Saudagaran (2005) asked the respondents to rank seven potential problems in using annual reports. The results indicated that a high proportion of responses $(52.7 \%)$ showed concern at the delay in the availability of published annual reports both overall and within five user-groups. Separate Kruskal-Wallis tests were carried out for each of the seven problems. The results show statistically significant differences among user-groups regarding their opinions about the lack of a comprehensive accounting system, lack of access to annual reports, lack of professional accountants, and lack of published accounting standards. But there is no statistically significant difference in users' opinions about the remaining three problems. Therefore, it can be concluded that all user groups believed that delays in publishing annual reports, lack of trust in information, and a lack of adequate information were areas of concern. According to Al-Attar and Al-Khater (2007), the first three most important reasons given for using sources other than corporate annual reports were that they provide new information, more useful and easy to get information. Preparation of them by neutral party and the relevancy of their information were the least important reasons respectively. Thus, investors try to obtain information from different sources such as stock exchange reports, newspapers, government agencies, friends, stockbrokers, managers, trade journals and others (Mirshekary \& Saudagaran, 2005; Baker \& Haslem, 1973; Al-Ajmi, 2009; Al-Razeen \& Karbhari, 2004a, 2004b). This is because measurement of accounting information is not an easy task and depends on many internal and external factors (Bagaeva, 2008).

The above mentioned studies reviled mixed results. Furthermore, the previous studies used a limited number of other financial information sources and they put less emphasis on the role of electronic sources in providing the 
individual investors with the necessary information to take their optimal investment decision. This study incorporated a broad range of information sources to assess their extent of usage by individual investors in ASE.

\section{Sample Selection and Data Collection}

The current study aims to assess the extent of usage of other corporate financial information in comparison with the traditional source namely; corporate annual reports by individual investors in ASE. The study also aims to identify the main reasons that encourage the individual investors to use other financial sources. To achieve these objectives, a well designed questionnaire was sent to 160 respondents. A total of 103 questionnaires were collected including 94 usable questionnaires. This yielded a response rate of $58.8 \%$. This paper is one of many papers aimed to investigate the different sources of corporate financial information depending on the same questionnaire that filled by Jordanian investors in ASE in the beginning of 2012. However, Table 1 shows the demographic characteristics of the individual investors. Of these, Table 1 shows that $55.3 \%$ of the investors were aged above 50 years and about $56.4 \%$ of them had a bachelor degree or higher. These, however, are good indicators that the sample of this study is relevant and can give a reliable data. In addition, Table 1 shows the investment characteristics of Jordanian individual investors. The table shows that about $43.6 \%$ of the investors own 10000 shares or more in different sectors. This also gives a good indicator about the diversity of investment portfolio for Jordanian individual investors.

\section{Insert Table 1 Here}

\section{Results and Discussion}

\subsection{Extent of Usage of Other Financial Information Sources}

The first research objective attempts to determine the extent of usage of a set of other corporate information sources among Jordanian individual investors. These sources include stockholders' advice, published daily share price, discussion with company staff, newspaper and magazine, advice of friends, tips and rumours and corporate web sites. The investigation is mainly conducted in comparison with corporate annual reports. Table 2 shows the usage frequency in terms of the relative weight placed on each of the information source, as well as the mean and standard deviation for each source. The results presented in the table showed that corporate annual report was ranked as "used to a great extent" or "used to a very great extent" by about $54.3 \%$ of the Jordanian individual investors with a means of 3.52. Thus, the corporate annual report was the most used sources of information by Jordanian individual investors. In respect to the other information sources, the published daily share price was ranked second as it ranked as "used to a great extent" or "used to a very great extent" by about $53.2 \%$ with a mean of 3.33 . This, however, is expected as most of Jordanian individual investors used to attending the trading room of shares in ASE using special monitors including the daily share prices. Newspapers and magazines were ranked third. This result is almost consistent with that of Al-Abdulqader et al. (2007) who found that Saudi investors were ranked newspapers as the second in terms of their extent of usage (see also Scott \& Smith, 1992). Corporate web sites were ranked fourth with a mean of 3.02. This result is a positive indicator about the trend for the future usage of electronic sources by Jordanian individual investors. This result, however, contradicts the argument of Loibl and Hira (2009) which assumes that an information source on financial markets can only to some limited extent become automatic. This followed by advice of friend, tips and rumours, stockbrokers' advice and discussion with company staff respectively. This result indicated that Jordanian individual investors put more emphasis on the usage of written financial information sources and avoid the usage of verbal sources such as stockbrokers' advice and discussion with company staff.

\section{Insert Table 2 Here}

\subsection{Reasons of Usage Other Corporate Information Sources}

The second research objective attempts to identify the main reasons that encourage the individual investors to use other corporate financial information sources other than corporate annual reports. To recall from the previous analysis, individual investors use other information sources such as published daily share price, newspapers and magazines and corporate web site to a considerable extent. Thus, six expected reasons were suggested for such usage and individual investors were asked to indicate the importance of each. These reasons were adapted from previous studies in the field (Abu-Nassar \& Rutherford, 1996; Al-Attar \& Al-Khater, 2007).

Table 3 shows that the most important reason for using alternative information sources was that they easier to get information as they ranked as "important to a great extent" or "important to a very great extent" by about $54.3 \%$ with a mean of 3.41. The second and third important reasons were that they contain new information and that they give up-to-date information respectively. This result is consistent with that of Mirshekary and Saudagaran (2005) which indicated that annual reports were deficient in providing the necessary information due to a lack of adequate 
detail and a delay in publishing. To this point, these results supported the previous result which indicated that Jordanian individual investors put more emphasis on the usage of written sources more than verbal sources. This is because written sources are easier to get information and contain new and up-to-date information than verbal one. This argument is almost similar to that of Al-Attar and Al-Khater (2007) which argued that these types of results give a good indicator about the reliability of the collected data. The fourth important reason for using alternative information sources other than corporate annual reports is that they are more understandable with a mean of 3.16. This reason as it comes at the bottom of the list means that Jordanian individual investors not face any problems in understanding the corporate annual reports contents. This result almost consistent with that of Abu-Nassar and Rutherford (1996) and contradicts that of Scott and Smith (1992). This result also supported the demographic characteristics of respondents which indicated that Jordanian investors were well-educated as $56.3 \%$ of them had a bachelor degree or higher (Scott \& Smith, 1992). Two reasons namely; they are more useful and they contain more relevant information were ranked the least important with a mean of 3.14 for each of them. Supplementary analysis has also been conducted using One Sample T-test (Table 4). The result of One sample T-test indicated that the t-value for each of the six reasons that encouraged investors to use other sources of information is significant $(p=0.000)$.

Insert Table 3 Here

Insert Table 4 Here

\section{Summary and Conclusion}

This study was designed to provide insight into of the extent of usage of other corporate financial information sources by Jordanian individual investors in taking their investment decisions in the ordinary shares of publicly quoted companies listed at the ASE in comparison with corporate annual reports. Furthermore, the study aims to identify the main reasons for using sources of information other than corporate annual reports. The result of study indicated that corporate annual reports were the most used sources of information by Jordanian individual investors. This followed by published daily share price, newspapers and magazines, corporate web sites, advice of friend, tips and rumours, stockbrokers' advice and discussion with company staff respectively. These results indicated that Jordanian individual investors give more weight to the usage of the written corporate information sources rather than verbal sources. This is clear as the verbal sources were ranked at the bottom of the list. The results also indicated that Jordanian individual investors start to give more attention to the usage of electronic sources as the corporate web sites ranked forth. In respect to reasons that encouraged investors to use sources of information other than corporate annual reports. The results of study indicated that the first three reasons include; easier to get information, containing new information and giving up-to-date information. These reasons form the features of the written sources which were indicated as the most used sources of information. This, however, indicates a consistency in the response of individual investors which support the reliability of the study as a whole. The last three reasons include; more understandable, more useful and more relevant information. These three reasons not contributed significantly in using other sources of information. This, however, is a good indicator about the ability of individual investors in analysing and understanding any sophisticated information. However, results from One Sample T-test indicated that all the listed six reasons were significant. This, however, means that these reasons -as a whole- contributed significantly toward using sources of information other than corporate annual reports.

Like any research study, the results have to be considered in light of some limitations. The current study adopted a cross-sectional design, which was conducted at one point in time and did not show the use of different sources of information over time. In addition, the study used a primarily quantitative approach as the main research methodology. The study also directed this study to the individual investors only, while many other groups are active in ASE.

Despite these limitations, this research provided useful insights on the state of different sources of corporate information sources in Jordan. The limitations of this study create many possibilities for future research. Thus, future research should be conducted using qualitative approach and investigated many other issues related to the usage, limitations, importance and contents of different corporate information sources in Jordan and other developing countries. Finally, future project could use larger sample, additional groups and more powerful statistical analytical methods to investigate different issues of financial reporting in Jordan and other developing countries.

\section{References}

Abdelsalam, O., \& Street, D. (2007). Corporate governance and the timeliness of corporate internet reporting by U.K. listed companies. Journal of International Accounting, Auditing and Taxation, 16, 111-130. http://dx.doi.org/10.1016/j.intaccaudtax.2007.06.001 
Abu-Nassar, M., \& Rutherford, B. A. (1995). Preparers' attitudes to financial reporting in less developed countries with moderately sophisticated capital markets: the case of Jordan. The International Journal of Accounting, 30, 129-38.

Abu-Nassar, M., \& Rutherford, B. A. (1996). External users of financial reports in less developed countries: the case of Jordan. British Accounting Review, 28, 73-87. http://dx.doi.org/10.1006/bare.1996.0004

Al-Abdulqader, K. A., Hannah, G., \& Power, D. M. (2007). The appraisal of ordinary shares by Saudi investors. Research in International Business and Finance, 21, 69-86. http://dx.doi.org/10.1016/j.ribaf.2005.08.004

Al-Ajmi, J. (2009). Investors' use of corporate reports in Bahrain. Managerial Auditing Journal, 24(3), 266-28. http://dx.doi.org/10.1108/02686900910941140

Al-Attar, J. M., \& Al-Khater, K. (2007). An empirical investigation of users' views on corporate annual reports in Qatar. International Journal of Commerce \& Management, 17(4), 312-325. http://dx.doi.org/10.1108/10569210710844381

Alford, A., Jones, J., Leftwich, R., \& Zmijewski, M. (1993). The relative informativeness of accounting disclosures in different countries. Studies on International Accounting, 31, 183-223. http://dx.doi.org/10.2307/2491170

Al-Razeen, A., \& Karbhari, Y. (2004a). Users' perceptions of corporate information in Saudi-Arabia: An empirical analysis'. International Journal of Commerce and Management, 14(3/4) 41-57. http://dx.doi.org/10.1108/10569210480000183

Al-Razeen, A., \& Karbhari, Y. (2004b). Annual corporate information: importance and use in Saudi Arabia. Managerial Auditing Journal, 19(1), 117-33. http://dx.doi.org/10.1108/02686900410509910

Al-Razeen, A., \& Karbhari, Y. (2007). An empirical investigation into the importance, use, and technicality of Saudi annual corporate information. Advances in International Accounting, 30, 55-74. http://dx.doi.org/10.1016/S08973660(07)20003-0

Bagaeva, A. (2008). An examination of the effect of international investors on accounting information quality in Russia. Advances in Accounting, 24(2), 157-161. http://dx.doi.org/10.1016/j.adiac.2008.08.001

Baker, H. K., \& Haslem, J. A. (1973). Information needs of individual investors. Journal of Accountancy, 136(5), 64-69.

Bartlett, S., \& Chandler, R. (1997). The corporate report and the private shareholder: Lee and Tweedie twenty years on. British Accounting Review, 29(3), 245-261. http://dx.doi.org/10.1006/bare.1996.0044

Courtis, J. (2004). Corporate report obfuscation: artefact or phenomenon?. The British Accounting Review, 36, 291-312. http://dx.doi.org/10.1016/j.bar.2004.03.005

Loibl, C., \& Hira, T. K. (2009). Investor information search. Journal of Economic Psychology, 30, $24-41$. http://dx.doi.org/10.1016/j.joep.2008.07.009

Mirshekary, S., \& Saudagaran, S. M. (2005). Perceptions and characteristics of financial statement users in developing countries: evidence from Iran. Journal of International Accounting, Auditing \& Taxation, 14, 33-54. http://dx.doi.org/10.1016/j.intaccaudtax.2005.01.001

Scott, R. N., \& Smith, C. (1992). Corporate Annual Reports and the Information Needs of Individual Investors. Journal of Business \& Finance Librarianship, 1(3), 3-18. http://dx.doi.org/10.1300/J109v01n03_02 
Table 1. Background Information of Participants

\begin{tabular}{|c|c|c|}
\hline Respondent & Investors Number & Investors Rate (\%) \\
\hline \multicolumn{3}{|l|}{ Gender } \\
\hline Male & 88 & 93.6 \\
\hline Female & 6 & 6.4 \\
\hline Total & 94 & 100 \\
\hline \multicolumn{3}{|l|}{ Age group } \\
\hline Under 30 & 8 & 8.5 \\
\hline $30-40$ & 16 & 17 \\
\hline $41-50$ & 18 & 19.1 \\
\hline Over 50 & 52 & 55.3 \\
\hline Total & 94 & 100 \\
\hline \multicolumn{3}{|l|}{ Education qualification } \\
\hline $\mathrm{PhD}$ & 1 & 1.1 \\
\hline Master & 5 & 5.3 \\
\hline Bachelor & 47 & 50 \\
\hline Diploma & 30 & 31.9 \\
\hline Others & 11 & 11.7 \\
\hline Total & 94 & 100 \\
\hline \multicolumn{3}{|l|}{ Degree field } \\
\hline Accounting & 27 & 28.7 \\
\hline Business administration & 15 & 16 \\
\hline Economics & 9 & 9.6 \\
\hline Finance & 5 & 5.3 \\
\hline Others & 38 & 40.4 \\
\hline Total & 94 & 100 \\
\hline \multicolumn{3}{|l|}{ Shares owned } \\
\hline Fewer than 1000 & 8 & 8.5 \\
\hline 1000 to 3999 & 15 & 16 \\
\hline 4000 to 7999 & 15 & 16 \\
\hline 8000 to 9999 & 15 & 16 \\
\hline 10000 or more & 41 & 43.6 \\
\hline Total & 94 & 100 \\
\hline \multicolumn{3}{|l|}{ Investors' sector of focus } \\
\hline Banking & 31 & 33 \\
\hline Insurance & 11 & 11.7 \\
\hline Manufacturing & 50 & 53.2 \\
\hline Trading & 35 & 37.2 \\
\hline Services & 73 & 77.7 \\
\hline Mining & 12 & 12.8 \\
\hline Others & 6 & 6 \\
\hline
\end{tabular}

Table 2. Extent of Usage of Different Corporate Information Sources in Comparison with Corporate Annual Report

\begin{tabular}{|c|c|c|c|c|c|c|}
\hline \multirow{2}{*}{ Corporate information source } & \multicolumn{4}{|c|}{ Extent of usage } & \multirow{2}{*}{ Mean } & \multirow{2}{*}{ S.D } \\
\hline & $\%$ rating 1 & $\%$ rating 2 & $\%$ rating 3 & $\%$ rating $4 \& 5$ & & \\
\hline Corporate annual reports & 8.5 & 11.7 & 25.5 & 54.3 & 3.52 & 1.24 \\
\hline Stockbrokers' advice & 26.6 & 29.8 & 22.3 & 21.3 & 2.45 & 1.21 \\
\hline Published daily share price & 10.6 & 14.9 & 21.3 & 53.2 & 3.33 & 1.22 \\
\hline Discussion with company staff & 35.1 & 21.3 & 17.0 & 26.5 & 2.43 & 1.34 \\
\hline Newspapers and magazines & 12.8 & 23.4 & 23.4 & 40.4 & 3.05 & 1.26 \\
\hline Advice of friends & 10.6 & 30.9 & 25.5 & 33.0 & 2.85 & 1.09 \\
\hline Tips and rumours & 30.9 & 19.1 & 24.5 & 25.6 & 2.57 & 1.38 \\
\hline Corporate web sites & 20.2 & 18.1 & 17.0 & 44.7 & 3.02 & 1.39 \\
\hline
\end{tabular}


Table 3. The Importance of Reasons That Lead to the Usage of Other Corporate Information Sources Other than Corporate Annual Reports

\begin{tabular}{lllllll}
\hline \multirow{2}{*}{ Reason } & \multicolumn{2}{l}{ Importance } & & & \multirow{2}{*}{ Mean } & S.D \\
\cline { 2 - 5 } & \% rating 1 & \% rating 2 & \% rating 3 & \% rating 4 \& 5 & & \\
\hline They contain new information & 6.4 & 21.3 & 29.8 & 42.6 & 3.21 & 1.12 \\
They are more useful & 5.3 & 26.6 & 29.8 & 38.3 & 3.14 & 1.11 \\
They are more understandable & 5.3 & 25.5 & 28.7 & 40.4 & 3.16 & 1.10 \\
They contain more relevant information & 5.3 & 28.7 & 26.6 & 39.3 & 3.14 & 1.14 \\
They give up-to-date Information & 9.6 & 20.2 & 27.7 & 42.6 & 3.18 & 1.20 \\
They are easier to get information & 7.4 & 13.8 & 24.5 & 54.3 & 3.41 & 1.14 \\
\hline
\end{tabular}

Table 4. One Sample T-test / Reasons That Lead to the Usage of Other Corporate Information Sources Other than Corporate Annual Reports

\begin{tabular}{|c|c|c|c|c|}
\hline Reason & Mean & S.D & t-value & Sig. \\
\hline They contain new information & 3.21 & 1.12 & 27.921 & 0.000 \\
\hline They are more useful & 3.14 & 1.11 & 27.338 & 0.000 \\
\hline They are more understandable & 3.16 & 1.10 & 27.839 & 0.000 \\
\hline They contain more relevant information & 3.14 & 1.14 & 26.653 & 0.000 \\
\hline They give up-to-date Information & 3.18 & 1.20 & 25.699 & 0.000 \\
\hline They are easier to get information & 3.41 & 1.14 & 29.048 & 0.000 \\
\hline
\end{tabular}

